

\title{
EXAFS of Liquid As-Te Mixtures
}

T. Miyanaga, H. Hoshino, H. Ikemoto, M. Yuza, I. Yamamoto, H. Endo

\section{To cite this version:}

T. Miyanaga, H. Hoshino, H. Ikemoto, M. Yuza, I. Yamamoto, et al.. EXAFS of Liquid As-Te Mixtures. Journal de Physique IV Proceedings, 1997, 7 (C2), pp.C2-1001-C2-1002. 10.1051/jp4:19972115 . jpa-00255173

\section{HAL Id: jpa-00255173 https://hal.science/jpa-00255173}

Submitted on 1 Jan 1997

HAL is a multi-disciplinary open access archive for the deposit and dissemination of scientific research documents, whether they are published or not. The documents may come from teaching and research institutions in France or abroad, or from public or private research centers.
L'archive ouverte pluridisciplinaire HAL, est destinée au dépôt et à la diffusion de documents scientifiques de niveau recherche, publiés ou non, émanant des établissements d'enseignement et de recherche français ou étrangers, des laboratoires publics ou privés. 


\title{
EXAFS of Liquid As-Te Mixtures
}

\author{
T. Miyanaga, H. Hoshino*, H. Ikemoto**, M. Yuza, I. Yamamoto* and H. Endo*** \\ Faculty of Science, Hirosaki University, Hirosaki 036, Japan \\ * Faculty of Education, Hirosaki University, Hirosaki 036, Japan \\ ** Faculty of Science, Toyama University, Toyama 930, Japan \\ *** Faculty of Engineering, Fukui Institute of Technology, Fukui 910, Japan
}

\begin{abstract}
The EXAFS measurements on $\mathrm{As}$ and $\mathrm{Te} K$-edges of liquid $\mathrm{As}_{2} \mathrm{Te}_{3}$ have been carried out in the temperature range including the supercooled liquid state down to $330^{\circ} \mathrm{C}$. By curve-fitting analyses with two-shell model the bond lengths and the coordination numbers were determined. It is suggested that As atoms within a chain bridge neighbouring chains with decreasing temperature and the network structure with three-fold coordinated As and two-fold coordinated Te is formed near the glass transition temperature.
\end{abstract}

\section{INTRODUCTION}

An important part of the recent scientific effort on liquid chalcogenides has been directed towards the glass transition. In the present paper, we have tried to get information on the change in local structure using EXAFS technique when liquid $\mathrm{As}_{2} \mathrm{Te}_{3}$ is supercooled down to the glass transition temperature.

\section{EXPERIMENTAL}

The mixture was prepared in the same way as described elsewhere [1]. The liquid $\mathrm{As}_{2} \mathrm{Te}_{3}$ specimen was kept in thin quartz cell with thickness of $50 \mu \mathrm{m}$. The EXAFS experiments were made on As and Te $K$-edges of liquid $\mathrm{As}_{2} \mathrm{Te}_{3}$ at 500,400 , 370,350 and $330^{\circ} \mathrm{C}$, the latter three temperatures correspond to the supercooled liquid state of $\mathrm{As}_{2} \mathrm{Te}_{3}\left(\mathrm{~m} . \mathrm{p} .380^{\circ} \mathrm{C}\right.$ ). The EXAFS absorption spectra were recorded in transmission mode at BL-10B station of the Photon Factory in Tsukuba by using $\mathrm{Si}(311)$ channel-cut monochrometer with a beam energy of $3.0 \mathrm{GeV}$ and the storage ring current from 160 to $200 \mathrm{~mA}$.
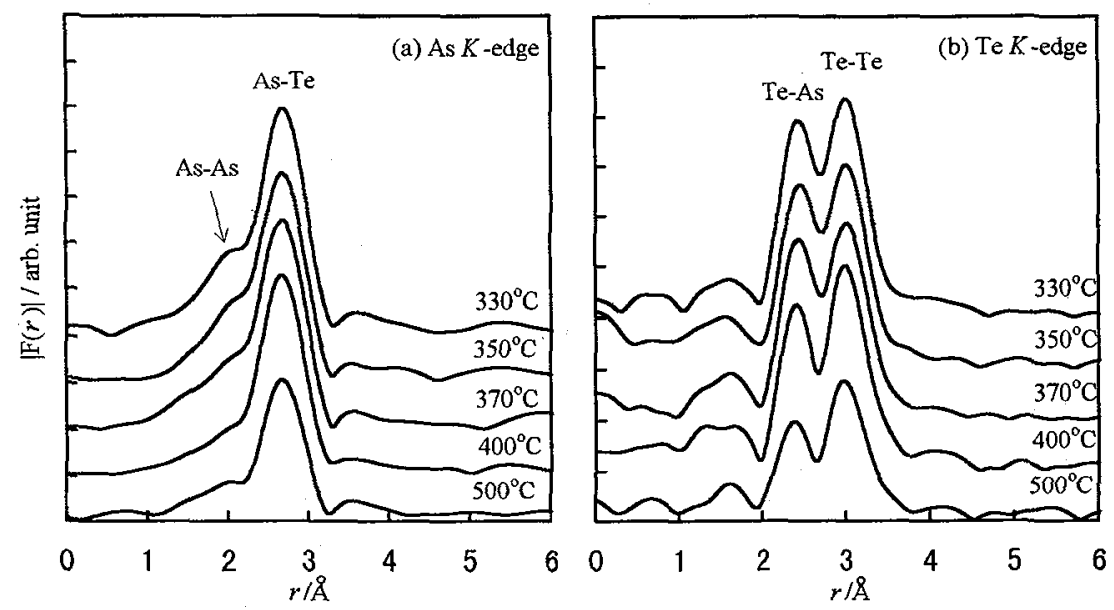

Figure 1: The magnitudes of the Fourier transformation of phase corrected $k \chi(k),|\mathrm{F}(r)|$, obtained around the central As atom (a) and Te atom (b) for liquid $\mathrm{As}_{2} \mathrm{Te}_{3}$ at different temperatures. 


\section{RESULTS AND DISCUSSION}

The EXAFS oscillations $\chi(k)$ were clearly detected up to $12 \AA^{-1}$ in the spectra. To derive the structural parameters, the two-shell curve-fitting analysis was carried out in the $k$ range from 3 to $12 \AA^{-1}$ by using the theoretical parameters calculated by the FEFF code [2,3]. Figure 1 shows $|\mathrm{F}(r)|$ around the central $\mathrm{As}(\mathrm{a})$ and $\mathrm{Te}(\mathrm{b})$ atoms for liquid $\mathrm{A} \mathrm{s}_{2} \mathrm{Te} \mathrm{e}_{3}$ at different temperatures including supercooling states, which was obtained by the Fourier transformation of phase corrected $k \chi(k)$. The main peaks and shoulders in Fig. 1(a) correspond to As-Te covalent bonds and As-As bonds. The two peaks in Fig.1(b) are associated with Te-As and Te-Te bonds. From the curve-fitting analyses, the As-Te bond length is estimated to be $2.62 \AA$, the As-As bond length $2.46 \AA$ and the Te-Te bond length $2.75 \AA$. The bond lengths are independent of temperature within experimental errors.

It is interesting to study how the local structure of liquid $\mathrm{As}_{2} \mathrm{Te}_{3}$ changes when the liquid specimen is cooled down to the glass transition temperature $T_{\mathrm{g}}\left(130^{\circ} \mathrm{C}\right.$ [4]) via the melting point $T_{\mathrm{m}}\left(380^{\circ} \mathrm{C}\right)$. However, it is difficult to get the glassy state unless the rate of cooling is fast because the glass forming ability for $\mathrm{As}_{2} \mathrm{Te}_{3}$ is rather poor. The temperature dependence of the coordination numbers, $N$, around the central As and Te atoms is shown in Figs. 2(a) and 2(b), respectively. The solid points in Figs. 2(a) and 2(b) are $N$ obtained for amorphous $\mathrm{As}_{2} \mathrm{Te}_{3}$ at $25^{\circ} \mathrm{C}$ by $\mathrm{Ma}$ et al. [4]; the total $N$ for the central As atom is 3.0 and that for the central Te 2.4. Nearly the same amounts of As-As and Te-Te bonds do exist in the liquid state, suggesting that the arrangement of unlike atom is not chemically ordered. The numbers of As-Te bonds around the central As atom, $N_{\mathrm{As}-\mathrm{Te}}$ and those of Te-As bonds around the central Te atom, $N_{\text {Te-As }}$ rapidly increase with decreasing temperature, while the rate of increase in $N_{\mathrm{As}-\mathrm{As}}$ and $N_{\mathrm{Te}-\mathrm{Te}}$ is small. The correlation between the neighbouring chains becomes stronger when fluctuations of the interchain coupling reduce with decreasing temperature and the diffusive motions of atoms are frozen below $T_{\mathrm{g}}$. The rapid increases of $N_{\mathrm{As}-\mathrm{Te}}$ and $N_{\mathrm{Te}-\mathrm{As}}$ encourage us to believe that As atoms within a chain bridge the neighbouring chains and the two dimensional network with three-fold coordinated As and two-fold coordinated $\mathrm{Te}$ is formed near $T_{\mathrm{g}}$, though the temperature range in the present measurements covers only the supercooled region down to $330^{\circ} \mathrm{C}$, not near $T_{\mathrm{g}}$.
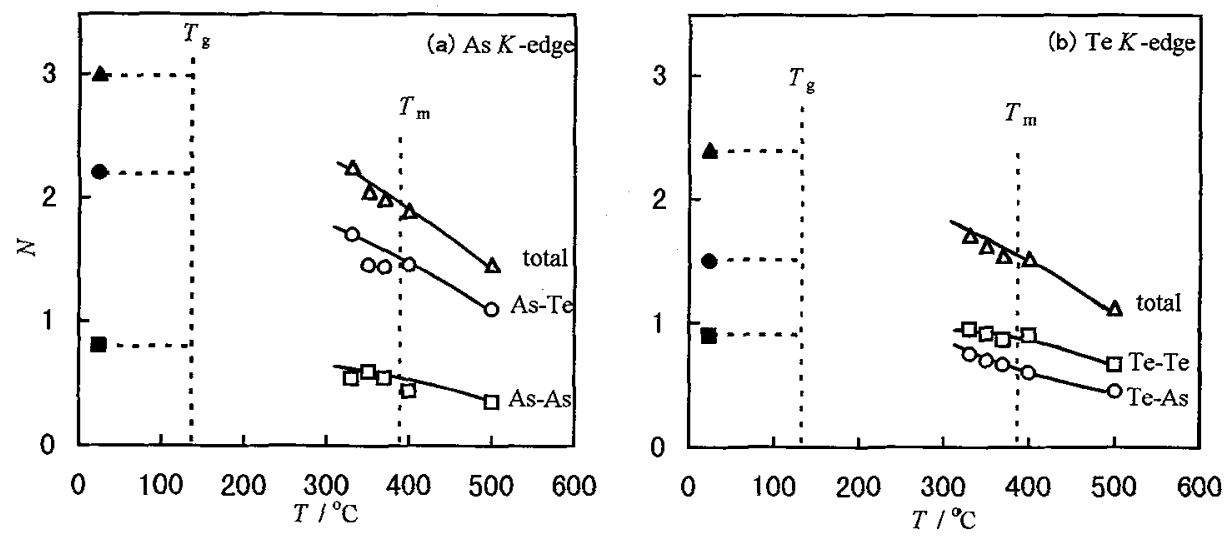

Figure 2: Variation with temperature of the coordination numbers $N$ around the central As atom (a) and Te atom (b) determined by curvefitting of the EXAFS data for liquid $\mathrm{As}_{2} \mathrm{Te}_{3}$. The solid points at $25^{\circ} \mathrm{C}$ are $N$ for amorphous $\mathrm{As}_{2} \mathrm{Te}_{3}$ from Ref. [4]. Lines are drawn as guides for the eye.

\section{Acknowledgements}

This work is partly indebted to Nippon Sheet Glass Foundation for Materials Science and Engineering for financial support. The authors are grateful to Dr. H. Sakane (Yamanashi University) for his support on the EXAFS experiments.

\section{References}

[1] Hoshino H., Miyanaga T., Kkemoto H., Hosokawa S. and Endo H., J. Non-Cryst. Solids, (1996) in press.

[2] Sakane H., Miyanaga T., Watanabe I., Matsubayashi N., Ikeda S. and Yokoyama Y., Jpn. J. Appl. Phys., 32 (1993) $4641-4647$.

[3] Rehr J. J., Mustre de Leon J., Zabinsky S. I. and Albers R. C., Phys. Rev. B, 44 (1991) 5135-5140.

[4] Ma Q., Raoux D. and Bénazeth S., Phys. Rev. B, 48 (1993) 16332-16346. 